\title{
Scheduling Supplementary Irrigation for Maize Production: Analysis of the Requirements for Climate Smart Farming for Rural Development
}

\author{
Fataw Ibrahim ${ }^{1,2}$, Boubacar Ibrahim ${ }^{1}$ \\ ${ }^{1}$ West African Center for Sustainable Rural Transformation (WAC-SRT), Faculté des Sciences et Techniques, Univerté Abdou \\ Moumouni de Niamey, Niamey, Niger \\ ${ }^{2}$ Faculty of Agriculture, University for Development Studies, Tamale, Ghana \\ Email: fatawibrahim123@gmail.com
}

How to cite this paper: Ibrahim, F. and Ibrahim, B. (2020) Scheduling Supplementary Irrigation for Maize Production: Analysis of the Requirements for Climate Smart Farming for Rural Development. Open Access Library Journal, 7: e6942.

https://doi.org/10.4236/oalib.1106942

Received: October 28, 2020

Accepted: November 24, 2020

Published: November 27, 2020

Copyright $\odot 2020$ by author(s) and Open Access Library Inc.

This work is licensed under the Creative Commons Attribution International License (CC BY 4.0).

http://creativecommons.org/licenses/by/4.0/

\begin{abstract}
The erratic rainfall pattern in sub Saharan Africa is a major threat to rainfed agriculture by consistently reducing yield due to water deficit and threatening food security. In order to address this problem, supplementary irrigation during the raining season is increasingly being encouraged to reduce water deficits during dry spells. The aim of this study is to design a supplementary irrigation for maize cropping during the raining season by using climatic data and water from surface runoff from a nearby catchment area. Climatic data for the study area was used to analyse the water requirement of maize during the rainy season and to propose an irrigation schedule. The results indicated that, out of $620.00 \mathrm{~mm}\left(3100 \mathrm{~m}^{3}\right)$ water requirement for the entire growing cycle of maize on a 0.5 ha field, the supplementary irrigation water requirement represents more than a third of the water need of maize during periods of dry spell in the maize crop cycle. With a reservoir volume of $600.00 \mathrm{~m}^{3}$ and a net irrigation application of $60 \mathrm{~mm}\left(300 \mathrm{~m}^{3}\right)$, about 5 irrigation applications (with a flow rate of $25.00 \mathrm{~m}^{3} / \mathrm{hr}$ for 6 hours a day) is required to supplement the irrigation water requirement of maize that can help alleviate soil moisture stress and increase crop yield during critical growth stages.
\end{abstract}

\section{Subject Areas \\ Agricultural Science}

\section{Keywords}

Supplementary Irrigation, Irrigation Scheduling, Rainfed Agriculture, Climate Smart Farming 


\section{Introduction}

Rain-fed agriculture accounts for about $80 \%$ of the world's farmland and two-thirds of global food production, nonetheless, about $41 \%$ of the Earth's land area is dryland with approximately 300 to $500 \mathrm{~mm}$ of erratic annual rainfall. Majority of the world rural farming population (82\%) depends on rainfed agriculture which is even higher in sub-Saharan Africa (93\%) (Aimé Sévérin et al., 2020) [1]. Two thirds of the world food production come from rainfed agriculture which has low productivity (about one third of its yield potential) as a result of moisture deficits that causes substantial yield losses and food insecurity (Nangia et al., 2018) [2].

Maize (Zea mays L.), an important cereal crop after wheat and rice with regards to cultivation area is usually grown under rainfed conditions in sub-Saharan Africa where water scarcity for agricultural production is expected to increase in a number of water deficit countries. Maize is an efficient user of water in terms of total dry matter production whose crop factor $(\mathrm{kc})$ relating to crop water requirements (Etc) with reference to evapo-transpiration (Eto) differs between growth stages (Wang et al., 2009) [3].

During the flowering and grain filling (mid-season to late season stages), shortage of soil moisture often occurs under rainfed conditions which can severely affect plant yield (Wang et al., 2009) [3]. The continuous water deficit during the flowering and the yield formation period determines the optimum irrigation method for maize production in the semi-arid areas (Uwizeyimana, 2018) [4]. "Supplemental irrigation which involves the addition of limited amounts of water to essentially rainfed crops to improve and stabilize yields when rainfall fails to provide sufficient moisture for normal plant growth" can help alleviate soil moisture stress and increase plant yield during critical growth stages (Nangia et al., 2018) [2]. Gembloux et al. (2015) [5] indicated farmers willingness to adopt supplementary irrigation techniques. However, financial constraints and knowledge for scheduling supplementary irrigation still remains a challenge to farmers and extension officers (Raju, 2016) [6].

The aim of this study is to explain the different steps needed in the design of a supplementary irrigation system for maize production during the raining season. The source of water is surface runoff that results after precipitation on a catchment area (watershed).

\section{Materials and Methods}

\subsection{Study Area}

The study area is located in south Niger at longitudes $2.5^{\circ} \mathrm{E}$ and latitudes $12.95^{\circ} \mathrm{N}$ (Figure 1). The study area is characterized with a Sudanese climate. The rainy season starts around mid-April and lasts till mid-September with annual rainfalls between $709 \mathrm{~mm}$ and $612 \mathrm{~mm}$. The maximum temperature in this area ranged from $26.0^{\circ} \mathrm{C}$ to $44.0^{\circ} \mathrm{C}$ and the minimum from $16.5^{\circ} \mathrm{C}$ to $30.5^{\circ} \mathrm{C}$. The relative humidity ranged from 8.6 to 96.4 . 


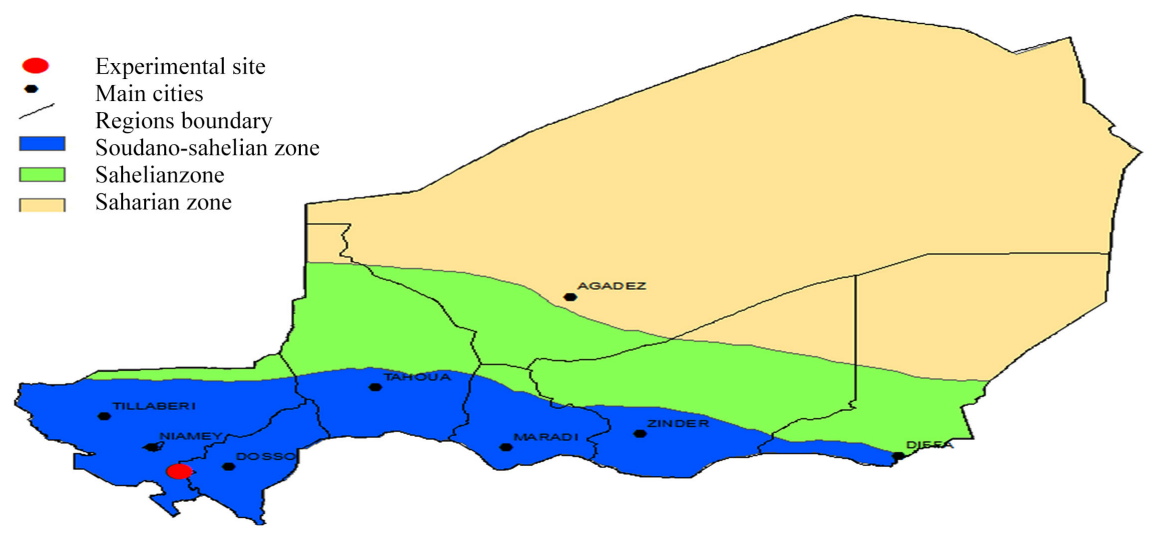

Figure 1. Location of the experimental site.

Four main soil types can be identified in the area: ferruginous soils, gravelly soils, vertisols and brown soils. The leached ferruginous soils are sandy on the surface and sandy/clayey at greater depth with low fertility levels.

The topography is very flat, with an average altitude of $280 \mathrm{~m}$. The vegetation is mostly characterized as arboreous and shrubby savannas. Agriculture is practiced as the main economic activity of the area where access to land is by kinship and inheritance. The main crops cultivated include millet, sorghum, maize, rice, groundnut, cowpea, cotton and soybean.

\subsection{Methodology Employed}

The Blanney-Criddle method is used to determine the reference crop evapotranspiration. The Blanney-Criddle method is based on measured data on temperature of a place hence it is simple and easy to understand. The Blaney-Criddle formula is expressed as: ETo $=p(0.46$ Tmean +8$)$ where ETo is the reference crop evapotranspiration ( $\mathrm{mm} /$ day) as an average for a period of 1 month, Tmean is the mean daily temperature (monthly values) $\left({ }^{\circ} \mathrm{C}\right)$ and $p$ is the mean daily percentage of annual daytime hours.

To determine the value of $p$, it is essential to know the approximate latitude of the area (the number of degrees north or south of the equator). The latitude of the study site is $12.95^{\circ} \mathrm{N}$ and the longitude is $2.5^{\circ} \mathrm{E}$. The mean daily percentage $(p)$ of annual daytime hours is calculated using linear extrapolation.

Linear extrapolation means creating a tangent line at the end of the known data and extending it beyond that limit. Linear extrapolation will only provide good results when used to extend the graph of an approximately linear function or not too far beyond the known data. If the two data points nearest to the point $x$ to be extrapolated are $\left(x_{1}, y_{1}\right)$ and $\left(x_{2}, y_{2}\right)$, linear extrapolation gives the function: $y=y_{2}+\left(y_{1}-y_{2}\right) *\left(x_{2}-x\right) /\left(x_{2}-x_{1}\right)$ which is identical to linear interpolation if $x_{1}<x<x_{2}$.

The crop water need ( $\mathrm{mm}$ per day) was determined using the formula: $E T$ crop $=E T o \times K c$, where $E T$ crop $=$ crop water need $(\mathrm{mm} /$ day $), K c=$ crop factor, $E T o=$ reference evapotranspiration ( $\mathrm{mm} /$ day). 
To determine the crop factor $K c$, it is necessary, for each crop, to know the total length of the growing season and the lengths of the various growth stages. The total growing period (in days) is the period from sowing to the last day of the harvest. It is mainly dependent on: the type of crop and the variety, the climate and the planting date. The total growing period is divided into 4 growth stages with their corresponding crop factors.

According to the FAO software "CROPWAT", Maize (grain) have a total maturity period of 125 days divided into Initial Stage (20 days), Development Stage (35 days), Mid-season (40 days) and Late Season (30 days) with Crop Coefficients of $0.30,1.20$ and 0.35 for the various stages of the crop life cycle.

Secondary data on rainfall, minimum and maximum temperatures as well as relative humidity from a close meteorological station was used in this study. Other relevant information was sourced from FAO and climatedata.org/Niger for the study area. The data was analyzed using Microsoft excel.

\section{Results and Discussions}

This section includes description and explanation to main results obtained. It consists of results obtained in the determination of annual daytime hours for the study location that was used to evaluate the daily water requirement of maize in order to provide the required irrigation schedule for maize that has the potential to increase maize productivity.

\subsection{Design of the Supplementary Irrigation System}

In Figure 2, a simple schematic diagram of the proposed irrigation system is illustrated. The system has a reservoir that receives water from a catchement area through pipes. The store water is used to irrigate the cultivated maize during periods of dry spells.

\subsection{Determination of the Annual Day Time Hours $(p)$}

Extrapolation is used to find the value of $p$ at a latitude of $12.95^{\circ} \mathrm{N}$ for the months in the year. Extrapolation is a type of estimation beyond the original observation range, the value of a variable on the basis of its relationship with another variable. Interpolation produces estimates between two known observations. The value of $p$ at $10^{\circ} \mathrm{N}$ and at $15^{\circ} \mathrm{N}$ can be found in FAO irrigation manual. Interpolation between these known values is used to estimate the value of $p$ at $12.95^{\circ} \mathrm{N}$ as presented in Table 1 .

\subsection{Evaluation of Water Needs}

The crop water need for maize was evaluated for the growing season to determine soil water inputs from precipitation as well as the irrigation water requirement for maize. This can help us determine the amount of water to harvest as well as the capacity of the reservoir that is needed to hold water for successful irrigation scheduling. 


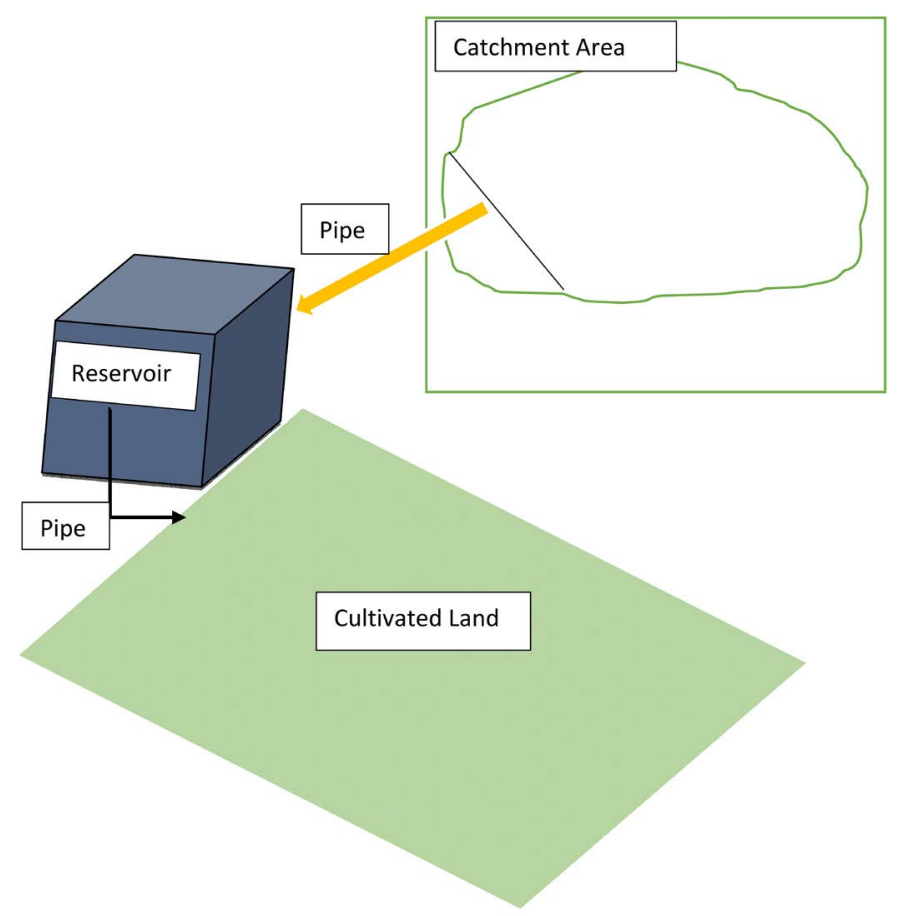

Figure 2. Simple schematic diagram of the proposed irrigation system.

Table 1. Linear interpolation of mean daily percentage $(p)$ of annual daytime hours for latitude $12.95^{\circ} \mathrm{N}$.

\begin{tabular}{cccc}
\hline Months & $p$ at $10^{\circ} \mathrm{N}$ & $p$ at $15^{\circ} \mathrm{N}$ & $p$ at $12.95^{\circ} \mathrm{N}$ \\
\hline January & 0.26 & 0.26 & 0.26 \\
February & 0.27 & 0.26 & 0.2641 \\
March & 0.27 & 0.27 & 0.27 \\
April & 0.28 & 0.28 & 0.28 \\
May & 0.28 & 0.29 & 0.2941 \\
June & 0.29 & 0.29 & 0.29 \\
July & 0.29 & 0.29 & 0.29 \\
August & 0.28 & 0.28 & 0.28 \\
September & 0.28 & 0.28 & 0.28 \\
October & 0.27 & 0.27 & 0.27 \\
November & 0.26 & 0.26 & 0.26 \\
December & 0.26 & 0.25 & 0.2541 \\
\hline
\end{tabular}

\subsection{Crop Water Requirement for Maize}

The estimated crop water requirement of maize for the whole growing season is $620.00 \mathrm{~mm}\left(3100.00 \mathrm{~m}^{3}\right)$. Crop water requirement is the amount of water needed by the crop during growth from sowing to harvesting. The water requirement for a crop depends on the crop type (crops like maize or sugarcane needs more water than millet or sorghum), the growth stage of the crop (fully grown crops 
need more water than crops that have just been planted) and the climate (in a sunny and hot climate crops need more water per day than in a cloudy and cool climate). This amount of water should be available to the plant to achieve it potential yield (Wang et al., 2020) [7]. However, part of this water requirement will be satisfied by precipitation (Wang et al., 2009) [3] so its therefore necessary to determine the irrigation water requirement during the maize growth cycle.

\subsection{Volume of Water Needed for Maize Production}

For the purpose of the design of a water storage system, its essential to determine the volume of water that is needed for the cultivation of the maize crop on a particular area of land. Hence, the Volume of water needed $=P m \times S \times 10^{-3}$; where $P m$ is the water requirement of maize, $S$ is the surface area to be cultivated ( 0.5 hectares $=5000 \mathrm{~m}^{2}$ ) and $10^{-3}$ is the conversion factor from $\mathrm{mm}$ to $\mathrm{m}$. Volume of water needed $=620.00 \mathrm{~mm} \times 5000 \mathrm{~m}^{2} \times 10^{-3}=3100.00 \mathrm{~m}^{3}$.

Therefore, the volume of water needed to cultivate maize on an area of 0.5 ha for the entire growing season is $3100.00 \mathrm{~m}^{3}$.

\subsection{Irrigation Water Requirement}

The estimated irrigation water requirement is $300 \mathrm{~mm}\left(1500.00 \mathrm{~m}^{3}\right)$. Irrigation water requirement is the part of water requirement for plant growth that should be added through irrigation to stabilize yield production (Pujara, 2016). Irrigation water is the difference between crop evapotranspiration and effective rainfall plus any soil water content or ground water contribution in the soil profile. Since there is loss of water through soil evaporation, the irrigation water requirement must account for it. The irrigation water requirement is therefore calculated as the difference between effective rainfall and crop water need plus water loss due to soil evaporation. When soil water is below $7 \mathrm{~mm}$, irrigation is required, so irrigation water requirement must account for it as well as any irrigation water loss due to inefficiency of the irrigation system. Table 2 illustrates the monthly water budget during the maize growing period of maize indicating the irrigation water requirement for each month for the study area in terms of gross irrigation application dose.

Table 2. Monthly Water budget for the maize growing season.

\begin{tabular}{|c|c|c|c|c|}
\hline Month & $\begin{array}{l}\text { Crop Water } \\
\text { Requirement } \\
(\mathrm{mm})\end{array}$ & $\begin{array}{l}\text { Effective Rainfall } \\
(\mathrm{mm})\end{array}$ & $\begin{array}{l}\text { Soil Evaporation } \\
\qquad\left(\mathrm{m}^{3}\right)\end{array}$ & $\begin{array}{c}\text { Irrigation Water } \\
\text { Requirement } \\
(\mathrm{mm})\end{array}$ \\
\hline May & 27.64 & 53.80 & 26.54 & 60.00 \\
\hline June & 124.21 & 92.50 & 48.24 & 120.00 \\
\hline July & 194.09 & 173.50 & 34.86 & 60.00 \\
\hline August & 186.05 & 328.70 & 24.18 & 0.00 \\
\hline September & 85.24 & 62.00 & 18.90 & 60.00 \\
\hline
\end{tabular}




\subsection{Irrigation Scheduling}

Irrigation scheduling is the process used by irrigation system managers to determine the correct frequency and duration of watering. Irrigation scheduling involves deciding when and how much water to apply to a field. Good scheduling will apply water at the right time and in the right quantity in order to optimize production and minimize adverse environmental impacts (Pujara, 2016) [8]. The goal of irrigation scheduling is to apply enough water to fully wet the plants root zone while minimizing overwatering and then allow the soil to dry out in between watering to allow air to enter the soil, encourage root development, efficient use of nutrients and prevent water stress (Pujara, 2016) [8].

Irrigation scheduling influences the agronomic and economic viability of small farms through water saving and improved yield (Nangia et al., 2018) [2]. Scheduling an irrigation depends on soil water status and crop water requirement. Therefore, for efficient management of the supplementary irrigation schedule, if soil water deficit (effective rainfall - Evapotranspiration) is less than 7, irrigation is required, but if its greater, no irrigation is required (Table 3 ).

However, it is necessary to know the volume of water to apply (net irrigation depth) and at what interval to ensure that, crops do not suffer from undue water shortages during the months of peak irrigation periods or over watering in periods of low water demand and to ensure the availability of water in the reservoir for the entire growing season. So, we proceed to determine the following.

Table 3. Daily irrigation schedule and reservoir water balance for the entire maize growing season.

\begin{tabular}{|c|c|c|c|c|c|}
\hline Date & $\begin{array}{l}\text { Crop Water } \\
\text { Need }(\mathrm{mm})\end{array}$ & $\begin{array}{l}\text { Effective Rainfall } \\
\qquad(\mathrm{mm})\end{array}$ & $\begin{array}{l}\text { Soil Evaporation } \\
\qquad(\mathrm{mm})\end{array}$ & $\begin{array}{l}\text { Irrigation } \\
\text { Schedule }\end{array}$ & $\begin{array}{l}\text { Net Irrigation } \\
\text { Application }\end{array}$ \\
\hline 17-May & & & Planting Date & & \\
\hline 18-May & 1.94 & 0.00 & 1.90 & No irrigation & \\
\hline 19-May & 2.07 & 0.00 & 2.24 & No irrigation & \\
\hline 20-May & 2.05 & 0.00 & 1.84 & No irrigation & \\
\hline 21-May & 1.99 & 0.00 & 1.64 & No irrigation & \\
\hline 22-May & 2.06 & 0.00 & 1.60 & Irrigation & 60.00 \\
\hline 23-May & 1.98 & 2.90 & 1.96 & No irrigation & \\
\hline 24-May & 2.00 & 0.00 & 2.06 & No irrigation & \\
\hline 25-May & 2.03 & 0.00 & 2.16 & No irrigation & \\
\hline 26-May & 1.85 & 3.90 & 1.92 & No irrigation & \\
\hline 27-May & 1.94 & 0.00 & 1.90 & No irrigation & \\
\hline 28-May & 1.82 & 23.00 & 2.14 & No irrigation & \\
\hline 29-May & 1.93 & 0.00 & 2.16 & No irrigation & \\
\hline 30-May & 2.03 & 0.00 & 1.86 & No irrigation & \\
\hline 31-May & 1.95 & 0.00 & 1.16 & No irrigation & \\
\hline
\end{tabular}




\section{Continued}

\begin{tabular}{|c|c|c|c|c|c|}
\hline 1-Jun & 1.89 & 0.00 & 1.62 & No irrigation & \\
\hline 2-Jun & 1.92 & 0.00 & 1.72 & No irrigation & \\
\hline 3-Jun & 1.94 & 0.00 & 1.44 & No irrigation & \\
\hline 4-Jun & 1.99 & 0.00 & 1.88 & No irrigation & \\
\hline 5-Jun & 2.04 & 0.00 & 1.80 & No irrigation & \\
\hline 6-Jun & 1.81 & 0.90 & 1.72 & No irrigation & \\
\hline 7-Jun & 4.82 & 0.00 & 2.00 & No irrigation & \\
\hline 8-Jun & 5.02 & 0.00 & 1.60 & No irrigation & \\
\hline 9-Jun & 4.97 & 0.00 & 1.32 & No irrigation & \\
\hline 10-Jun & 4.97 & 0.00 & 2.34 & Irrigation & 60.00 \\
\hline 11-Jun & 4.94 & 0.00 & 2.22 & No irrigation & \\
\hline 12-Jun & 4.64 & 0.90 & 2.52 & No irrigation & \\
\hline 13-Jun & 4.97 & 0.00 & 0.66 & No irrigation & \\
\hline 14-Jun & 5.07 & 0.00 & 1.30 & No irrigation & \\
\hline 15-Jun & 5.04 & 0.00 & 1.70 & No irrigation & \\
\hline 16-Jun & 4.51 & 18.90 & 2.08 & No irrigation & \\
\hline 17-Jun & 4.54 & 0.00 & 1.70 & No irrigation & \\
\hline 18-Jun & 4.77 & 0.00 & 1.54 & No irrigation & \\
\hline 19-Jun & 4.80 & 0.00 & 1.82 & No irrigation & \\
\hline 20-Jun & 4.39 & 8.00 & 1.50 & No irrigation & \\
\hline 21-Jun & 4.37 & 0.00 & 1.96 & No irrigation & \\
\hline 22-Jun & 4.69 & 0.00 & 0.90 & No irrigation & \\
\hline 23-Jun & 4.41 & 17.90 & 1.12 & No irrigation & \\
\hline 24-Jun & 4.39 & 0.00 & 1.60 & No irrigation & \\
\hline 25-Jun & 4.60 & 0.00 & 1.32 & No irrigation & \\
\hline 26-Jun & 4.84 & 0.00 & 1.60 & Irrigation & 60.00 \\
\hline 27-Jun & 4.71 & 0.00 & 1.22 & No irrigation & \\
\hline 28-Jun & 4.35 & 19.90 & 1.52 & No irrigation & \\
\hline 29-Jun & 4.62 & 0.00 & 1.42 & 1_irrigation & \\
\hline 30-Jun & 4.22 & 26.00 & 1.10 & No irrigation & \\
\hline 1-Jul & 4.52 & 0.00 & 1.48 & No irrigation & \\
\hline 2-Jul & 4.33 & 1.90 & 1.30 & No irrigation & \\
\hline 3-Jul & 4.64 & 0.00 & 0.90 & No irrigation & \\
\hline 4-Jul & 4.68 & 0.00 & 1.12 & No irrigation & \\
\hline 5-Jul & 4.31 & 1.90 & 0.78 & No irrigation & \\
\hline 6-Jul & 4.37 & 1.90 & 1.40 & No irrigation & \\
\hline 7-Jul & 4.55 & 3.90 & 1.20 & No irrigation & \\
\hline
\end{tabular}




\section{Continued}

\begin{tabular}{|c|c|c|c|c|c|}
\hline 8-Jul & 4.23 & 16.90 & 1.64 & No irrigation & \\
\hline 9-Jul & 4.65 & 0.00 & 1.66 & No irrigation & \\
\hline 10-Jul & 4.32 & 0.00 & 1.62 & No irrigation & \\
\hline $11-J u l$ & 4.64 & 0.00 & 1.48 & No irrigation & \\
\hline 12-Jul & 7.28 & 13.10 & 1.32 & No irrigation & \\
\hline 13-Jul & 7.24 & 0.00 & 0.84 & No irrigation & \\
\hline 14-Jul & 7.53 & 0.00 & 1.44 & No irrigation & \\
\hline 15-Jul & 7.47 & 0.00 & 1.40 & Irrigation & 60.00 \\
\hline 16-Jul & 6.83 & 0.00 & 0.76 & No irrigation & \\
\hline 17-Jul & 7.22 & 0.00 & 1.26 & No irrigation & \\
\hline 18-Jul & 6.91 & 2.90 & 1.60 & No irrigation & \\
\hline 19-Jul & 7.35 & 13.10 & 0.54 & No irrigation & \\
\hline 20-Jul & 7.11 & 39.00 & 1.36 & No irrigation & \\
\hline 21-Jul & 7.31 & 0.00 & 0.96 & No irrigation & \\
\hline 22-Jul & 7.39 & 0.00 & 0.64 & No irrigation & \\
\hline 23-Jul & 7.59 & 0.00 & 1.08 & No irrigation & \\
\hline 24-Jul & 7.75 & 0.00 & 1.04 & No irrigation & \\
\hline 25-Jul & 6.98 & 60.00 & 0.62 & No irrigation & \\
\hline 26-Jul & 7.31 & 0.00 & 0.60 & No irrigation & \\
\hline 27-Jul & 7.20 & 0.00 & 1.04 & No irrigation & \\
\hline 28-Jul & 6.86 & 0.00 & 0.54 & No irrigation & \\
\hline 29-Jul & 7.23 & 18.90 & 0.88 & No irrigation & \\
\hline 30-Jul & 7.16 & 0.00 & 0.98 & No irrigation & \\
\hline 31-Jul & 7.15 & 0.00 & 1.38 & No irrigation & \\
\hline 1-Aug & 7.09 & 0.00 & 0.54 & No irrigation & \\
\hline 2-Aug & 7.15 & 0.00 & 1.02 & No irrigation & \\
\hline 3-Aug & 6.51 & 36.90 & 1.10 & No irrigation & \\
\hline 4-Aug & 6.88 & 0.00 & 1.22 & No irrigation & \\
\hline 5-Aug & 7.06 & 0.00 & 0.54 & No irrigation & \\
\hline 6-Aug & 6.98 & 0.00 & 0.74 & No irrigation & \\
\hline 7-Aug & 6.75 & 60.00 & 0.64 & No irrigation & \\
\hline 8-Aug & 7.01 & 0.00 & 0.48 & No irrigation & \\
\hline 9-Aug & 7.12 & 0.00 & 0.62 & No irrigation & \\
\hline 10-Aug & 6.82 & 0.00 & 1.12 & No irrigation & \\
\hline 11-Aug & 7.00 & 60.00 & 0.42 & No irrigation & \\
\hline 12-Aug & 7.17 & 0.00 & 0.28 & No irrigation & \\
\hline 13-Aug & 6.24 & 39.00 & 0.22 & No irrigation & \\
\hline
\end{tabular}




\section{Continued}

\begin{tabular}{|c|c|c|c|c|c|}
\hline 14-Aug & 6.83 & 18.90 & 0.84 & No irrigation & \\
\hline 15-Aug & 7.05 & 0.00 & 0.66 & No irrigation & \\
\hline 16-Aug & 7.23 & 0.00 & 0.50 & No irrigation & \\
\hline 17-Aug & 6.54 & 59.00 & 0.70 & No irrigation & \\
\hline 18-Aug & 6.78 & 0.00 & 0.96 & No irrigation & \\
\hline 19-Aug & 6.98 & 0.00 & 1.16 & No irrigation & \\
\hline 20-Aug & 6.86 & 0.10 & 1.34 & No irrigation & \\
\hline 21-Aug & 4.46 & 0.00 & 0.66 & No irrigation & \\
\hline 22-Aug & 4.43 & 0.00 & 0.66 & No irrigation & \\
\hline 23-Aug & 4.56 & 0.00 & 0.84 & No irrigation & \\
\hline 24-Aug & 4.10 & 16.90 & 0.92 & No irrigation & \\
\hline 25-Aug & 4.32 & 11.00 & 0.64 & No irrigation & \\
\hline 26-Aug & 4.36 & 0.00 & 0.58 & No irrigation & \\
\hline 27-Aug & 4.50 & 2.90 & 0.62 & No irrigation & \\
\hline 28-Aug & 4.29 & 0.00 & 1.08 & No irrigation & \\
\hline 29-Aug & 4.47 & 0.00 & 1.26 & No irrigation & \\
\hline 30-Aug & 4.15 & 24.00 & 0.88 & No irrigation & \\
\hline 31-Aug & 4.34 & 0.00 & 0.94 & No irrigation & \\
\hline 1-Sep & 4.91 & 0.00 & 1.00 & No irrigation & \\
\hline 2-Sep & 4.42 & 0.00 & 1.32 & No irrigation & \\
\hline 3-Sep & 4.33 & 0.00 & 0.60 & No irrigation & \\
\hline 4-Sep & 4.37 & 25.00 & 0.84 & No irrigation & \\
\hline 5-Sep & 4.62 & 0.00 & 0.82 & No irrigation & \\
\hline 6-Sep & 4.39 & 27.00 & 0.74 & No irrigation & \\
\hline 7-Sep & 4.28 & 0.00 & 0.72 & No irrigation & \\
\hline 8-Sep & 4.49 & 0.00 & 1.26 & No irrigation & \\
\hline 9-Sep & 4.43 & 0.00 & 1.58 & No irrigation & \\
\hline 10-Sep & 4.49 & 0.00 & 1.08 & No irrigation & \\
\hline 11-Sep & 4.46 & 0.00 & 0.66 & No irrigation & \\
\hline 12-Sep & 4.59 & 0.00 & 1.10 & No irrigation & \\
\hline 13-Sep & 4.71 & 0.00 & 0.96 & No irrigation & \\
\hline 14-Sep & 4.42 & 0.00 & 1.00 & No irrigation & \\
\hline 15-Sep & 4.27 & 10.00 & 1.02 & No irrigation & \\
\hline 16-Sep & 4.47 & 0.00 & 1.12 & No irrigation & \\
\hline 17-Sep & 4.54 & 0.00 & 1.70 & Irrigation & 60.00 \\
\hline 18-Sep & 4.61 & 0.00 & 0.84 & No irrigation & \\
\hline 19-Sep & 4.47 & 0.00 & 0.54 & No irrigation & \\
\hline
\end{tabular}




\subsection{Effective Root Depth (D)}

This is the soil depth from which the plants take nearly 80 percent of their water needs, mostly from the upper part where the root system is denser. The rooting depths depend on the plant physiology, the type of soil, and the water availability (kind of irrigation) as well as stage of growing season. The maximum root depth of maize is estimated at $1.00 \mathrm{~m}$ during mid to late season.

\subsection{Total Available Water (TAW)}

Soil water availability refers to the capacity of a soil to retain water available to plants. After heavy rainfall or irrigation, the soil will drain until field capacity is reached. Field capacity is the amount of water that a well-drained soil should hold against gravitational forces, or the amount of water remaining when downward drainage has markedly decreased. The fraction of moisture in the soil which amounts to 20 - 70 percent of the total available moisture and is easily absorbed by the plants (without any stress that results in yield reduction) is called readily available moisture. The soil in the study area is a sandy loam soil with an estimated total soil available water of $90 \mathrm{~mm} / \mathrm{m}$ (Pujara, 2016) [6].

\subsection{Depletion of Soil Available Water ( $p$ )}

The maximum critical depletion fraction of maize is estimated at 0.675 with 0.8 at late season and 0.55 from initial through development to mid-season stages. This indicate the rate at which the total available water is depleted from the root zone of the plant. Several soil management practices improves water holding capacity of soils among which includes the use of biochar (Abukari, 2019 [9]; Oppong et al., 2019 [10]) which also provide long term soil properties like nematode management (Ibrahim, Quainoo and Kankam, 2019) [11], heavy metals sorption (Quainoo, Duwiejuah and Cobbina, 2019) [12], and agrochemicals sorption (Qiao et al., 2018 [13]; Sewu et al., 2019 [14]) and can mitigate climate change (Panwar et al., 2019 [15]; Hamedani et al., 2019 [16]; Gogoi et al., 2019 [17]).

\subsection{Net Depth of Irrigation Application (d)}

This is the amount of water applied per an irrigation application to replenish the depleted water. This depends on the root depth of the crop and the soil type. Net depth of irrigation dose $(d)(\mathrm{mm})=(S a \times p) D$; where $S a$ is the available water, $p$ is the permissible depletion (fraction) and $D$ is the root depth (Pujara, 2016). Hence the net depth of irrigation dose $=90 \mathrm{~mm} / \mathrm{m} \times 0.675 \times 1=60 \mathrm{~mm}(60 \mathrm{~mm}$ $\times 5000 \mathrm{~m}^{2} \times 10^{-3}=300 \mathrm{~m}^{3}$ ).

\subsection{Irrigation Interval or Frequency (i)}

The period between successive irrigations is the irrigation interval which is crucial in the plan and management of irrigation for desired productivity. Since crop water need varies with the crop stage of development, the irrigation interval 
will vary based on the stage of development of the crop as well as the amount of effective rainfall that is received during that period. So, when the soil cumulative water deficit is less than $7 \mathrm{~mm}, 60 \mathrm{~mm}$ of irrigation is applied (Table 3). The irrigation interval is less during periods of peak demand and high during periods of low water demand.

\subsection{The Number of Irrigation Applications over the Total Growing Season}

The number of irrigation applications is obtained by dividing the irrigation water need over the growing season by the net irrigation depth per application. The estimated irrigation water need is $300.00 \mathrm{~mm}$ and with a net irrigation application depth of $60 \mathrm{~mm}$. So, the number of irrigation applications is approximately 5. This indicates that, only 5 irrigation applications are sufficient to supplement the water need of maize for the growing period.

\subsection{System Flow}

The minimum flow capacity $(Q)$ of any irrigation system should be the one that can meet the water requirements of the area under irrigation at peak demand.

Minimum $Q=10 A^{*}(d g / i t)$; where $Q$ is the system flow in cubic meters per hour, $A$ is the area in hectares, $d g$ is the gross irrigation application depth (irrigation dose) in millimeters, $i$ is the interval in days between two irrigations at peak demand, $t$ is the operating hours per day, and 10 is a constant for hectares.

If one week (6 days) are allowed for repair of damages to the system or pumping unit so that the minimum flow enables the completion of irrigation at least one week before the next irrigation. The value of $i$ in the above formula should be reduced by six days. The peak demand is in July with an irrigation interval of 16 days. If the operating hours of the system are 6 hours per day.

Therefore, Minimum $Q=10^{*} A^{*}(d g / i t)$; with $A=0.5 \mathrm{ha}, d g=300 \mathrm{~m}^{3}, i=16$ $-6=10, t=6$. Minimum $Q=10 \times 0.5 \times(300 / 10 \times 6)=25.0 \mathrm{~m}^{3} / \mathrm{hr}$. Hence, the rate of flow of the reservoir storage system should be $25.0 \mathrm{~m}^{3} / \mathrm{hr}$.

\subsection{Reservoir Design and Monitoring}

Reservoirs are man-made water bodies designed to collect and store runoff water, modified or managed in order to provide water for developing human activities and demands (Zhang and Gao, 2020) [18]. They are found in areas of water scarcity or excess for controlled management of water resources by containing water during excess and providing it during scarcity in a reliable and controlled manner for irrigation of agricultural fields and other purposes. Reservoirs range in size from pond-like to large lakes of regular or irregular shapes with varied water quality depending on the water use. To achieve the desired water quality, reservoirs are designed in a way that allows for flexibility and control for human intervention.

The irrigation water requirement during the peak month is $120.00 \mathrm{~mm}$ $\left(120.00 \mathrm{~mm} \times 5000 \mathrm{~m}^{2} \times 10^{-3}=600.00 \mathrm{~m}^{3}\right)$. 
For the purpose of this project, we need a reservoir with a minimum volume of $600 \mathrm{~m}^{3}$ to be able to store water for irrigation during peak demands in the growing season.

\subsection{Water Harvest}

The source of water for the reservoir in this project is direct precipitation during the raining season on a watershed. This involves collecting runoff through an outlet into the reservoir. The volume of runoff water, $V$ is calculated by multiplying the size of the catchment area, $S$ that will collect runoff water in to the reservoir by the daily rainfall, $P m$ and a runoff coefficient, $\mu\left(V=\mu^{*} P m * S^{*}\right.$ $\left.10^{-3}\right)$.

The runoff coefficient is determined from the soil type and topography of the area. The project area is characterized by a sandy-loam soil with a slope of $5 \%$ $10 \%$. The runoff coefficient is estimated at 0.16 for the area.

\subsection{Reservoir Dimensions}

Assuming a rectangular reservoir of length, $L$, breadth, $B$ and a depth, $H$. Volume of a rectangle $=L \cdot B \cdot H$.

With a depth of $2.5 \mathrm{~m}$, breadth of $12 \mathrm{~m}$ and length of $20 \mathrm{~m}$, a volume of 600 $\mathrm{m}^{3}$ can be collected for irrigation. Therefore, the minimum configuration of the reservoir should be $2.5 \mathrm{~m} \times 12 \mathrm{~m} \times 20 \mathrm{~m}$ to be able to contain water for supplementary irrigation of maize.

\subsection{Reservoir Monitoring}

This is the assessment of water stored in the reservoir for irrigation for the entire growing cycle. Here, the volume of water in the reservoir should be more than the water requirement of the crop, water losses through evaporation from the surface of the reservoir as well as application losses. We propose that, water is removed from reservoir (pool) only by evaporation (Evap), the other losses are negligible. There is no water loss from tanks and pipes.

Water harvesting occurred on the first precipitation recorded before the planting date. The water balance account for the amount of water that is lost by crop evapotranspiration (ET) and the amount of water that enters the soil reservoir (as effective rain or irrigation). Water balance is based on the law of conservation of mass. That is, the sum of all inflows minus the sum of all outflows must equal the change in storage. This is necessary to ensure that, crops do not suffer from undue water shortages during the months of peak irrigation periods or over watering in periods of low water demand and ensure the availability of water in the reservoir for the entire growing season (Amjath-Babu et al., 2016 [19]; Sandeep et al., 2019 [20]; Tomaz et al., 2020 [21]; Wang et al., 2020 [7]).

The volume of water collected on the catchment area of $100 \mathrm{~m}^{2}$ during the first day of rainfall (planting date) of $20.4 \mathrm{~mm}$ was estimated at $326.4 \mathrm{~mm}$. Some 
of this water will be used for irrigation application whenever the available soil water is less than $7 \mathrm{~mm}$. The water balance in the reservoir is estimated by the difference between all water inputs (water harvest + previous water reserve) and water output (irrigation water + evaporation). In order to avoid shortages during the growing cycle, water harvest will be carried out whenever there is precipitation to refill the reservoir output due to irrigation and evaporation losses. Table 3 indicates the daily irrigation schedule for maize in the study area. The schedule is based on the difference between soil water inputs through precipitation (effective rainfall) and soil water losses through evaporation and the water need of the crop. When soil water input is less than soil water losses, no irrigation is required and vice versa. However, the net irrigation application $(60 \mathrm{~mm})$ satisfies water losses for a period taking into account soil water input from precipitation (effective rainfall).

\section{Conclusion}

The study explained scheduling supplementary irrigation as a water management strategy in a rural area for maize cultivation using soil saturation method. Climatic data was used in the estimation of the plant water requirement of maize as well as the volume of water needed to supplement the water requirements during periods of dry spells during the raining season. The data was analyzed using Microsoft excel and the results indicated the importance that supplementary irrigation water requirement accounts for over a third of the water need of maize which is crucial for agriculture and food security in the Sahel especially in the face of low precipitations and lower soil moisture content that can help alleviate soil moisture stress and increase plant yield during critical growth stages. Due to changes in precipitation patterns, we recommend frequent soil moisture monitoring in order to avoid moisture stress especially during critical growth stages of the crop.

\section{Acknowledgements}

The authors thank the West African Center for Sustainable Rural Transformation (WACSRT) and their sponsors (DAAD, BMBF) for their financial support under the Integrated Master Program for Sustainable Rural Transformation (IMP-SRT).

\section{Conflicts of Interest}

The authors declare no conflicts of interest regarding the publication of this paper.

\section{References}

[1] Kima, A.S., et al. (2020) Evaluating Supplementary Water Methodology with Saturated Soil Irrigation for Yield and Water Productivity Improvement in Semi-Arid Rainfed Rice System, Burkina Faso. Sustainability, 12, 4819.

https://doi.org/10.3390/su12124819 
[2] Nangia, V., et al. (2018) Supplemental Irrigation: A Promising Climate-Smart Practice for Dryland Agriculture.

[3] Wang, Y.M., Traore, S. and Kerh, T. (2009) Applying Evapotranspiration Reference Model and Rainfall Contribution Index for Agricultural Water Management Plan in Burkina Faso. African Journal of Agricultural Research, 4, 1493-1504.

[4] Uwizeyimana, D. (2018) Assessing the Effectiveness of Supplementary Irrigation and Soil Conservation Techniques on Maize in Cyili Sub-Catchment, Rwanda. University of Nairobi, Nairobi.

[5] Gembloux, L., et al. (2015) Farmers' Practices and Willingness to Adopt Supplemental Irrigation in Burkina Faso Beteo Zongo International Institute for Water and Environmental Engineering, Burkina Faso Centre de Coopération Internationale en Recherche Agronomique pour le Internati. International Journal of Food and Agricultural Economics, 3, 101-117.

[6] Raju, K.V. (2016) Financing Irrigation Development in Cambodia: Emerging Options. Asian Journal of Science and Technology, 7, 3031-3034.

http://www.journalajst.com

[7] Wang, H., et al. (2020) Monitoring and Statistical Methods of Irrigation Water Consumption of Wanyao Irrigation Area. IOP Conference Series. Earth and Environmental Science, 510, Article ID: 032025. https://doi.org/10.1088/1755-1315/510/3/032025

[8] Pujara, M. (2016) Criteria for Scheduling Irrigation. 19.

[9] Abukari, A. (2019) Influence of Rice Husk Biochar on Water Holding Capacity of Soil in the Savannah Ecological Zone of Ghana. Turkish Journal of Agriculture-Food Science and Technology, 7, 888-891.

https://doi.org/10.24925/turjaf.v7i6.888-891.2488

[10] Oppong, E., et al. (2019) Field Crops Research Impact of Rice Straw Biochar and Irrigation on Maize Yield, Intercepted Radiation and Water Productivity in a Tropical Sandy Clay Loam. Field Crops Research, 243, Article ID: 107628. https://doi.org/10.1016/j.fcr.2019.107628

[11] Ibrahim, F., Quainoo, A.K. and Kankam, F. (2019) Effect of Shea Nut Shell Biochar on Root Knot Nematodes (Meloidogyne spp.) of Tomato (Solanum lycopersicum L.). Annual Research \& Review in Biology, 30, 1-7. https://doi.org/10.9734/ARRB/2018/45187

[12] Quainoo, A.K., Duwiejuah, A.B. and Cobbina, S.J. (2019) Adsorption of Toxic Metals onto Eco-Friendly and Cost-Effective Shea (Vitellaria Paradoxa) Nut Shell Biochar in Aqueous Phase. UDS International Journal of Development, 6, 72-83.

[13] Qiao, K., et al. (2018) Preparation of Biochar from Enteromorpha Prolifera and Its Use for the Removal of Polycyclic Aromatic Hydrocarbons ( PAHs ) from Aqueous Solution. Ecotoxicology and Environmental Safety, 149, 80-87.

https://doi.org/10.1016/j.ecoenv.2017.11.027

[14] Sewu, D.D., et al. (2019) Physicochemical Property and Dye Uptake Capacity of Bentonite/Biochar Composite. Journal of the Taiwan Institute of Chemical Engineers, 12, 1-8.

[15] Panwar, N.L., Pawar, A. and Salvi, B.L. (2019) Comprehensive Review on Production and Utilization of Biochar. SN Applied Sciences, 1, Article No. 168. https://doi.org/10.1007/s42452-019-0172-6

[16] Hamedani, S.R., et al. (2019) Life Cycle Assessment and Environmental Valuation of Biochar Production: Two Case Studies in Belgium. Energies, 12, 2166. https://doi.org/10.3390/en12112166 
[17] Gogoi, L., et al. (2019) Biochar Production and Application in Forest Soils-A Critical Review. Phyton, International Journal of Experimental Botany Biochar, 88, 349-365. https://doi.org/10.32604/phyton.2019.08406

[18] Zhang, S. and Gao, H. (2020) Using the Digital Elevation Model (DEM) to Improve the Spatial Coverage of the MODIS Based Reservoir Monitoring Network in South Asia. Remote Sensing, 12, 745. https://doi.org/10.3390/rs12050745

[19] Amjath-babu, T.S., et al. (2016) Transitioning to Groundwater Irrigated Intensified Agriculture in Sub-Saharan Africa: An Indicator Based Assessment. Agricultural Water Management, 168, 125-135. https://doi.org/10.1016/j.agwat.2016.01.016

[20] Sandeep, S., Sahoo, B. and Singh, N. (2019) A SWAT-Copula Based Approach for Monitoring and Assessment of Drought Propagation in an Irrigation Command. Ecological Engineering, 127, 417-430. https://doi.org/10.1016/j.ecoleng.2018.11.021

[21] Tomaz, A., et al. (2020) Spatial and Temporal Dynamics of Irrigation Water Quality under Drought Conditions in a Large Reservoir in Southern Portugal. Environmental Monitoring and Assessment, 192, 93. https://doi.org/10.1007/s10661-019-8048-1 